\title{
Absenteeism-illness of education servers: profile of sick leaves in a federal institution
}

\author{
Bárbara de Oliveira Figueiredo'(i), Luiz Sérgio Silva'(i), \\ Renata Maria Colodette ${ }^{1}(\mathbb{1})$, Luiza Possa Pereira' ${ }^{(1)}$, \\ Larissa Bruna Bhering Silva'(i), Deíse Moura de Oliveira' ${ }^{1}$, \\ Tiago Ricardo Moreira'(i)
}

'Universidade Federal de Viçosa, Viçosa, MG, Brasil

\begin{abstract}
Investigated the factors associated to the number of days of sick leave of federal civil servants in an educational institution and the values of their occupational indices in the period from 2014 to 2017. Data sociodemographic, occupational and sick leaves were obtained through documentary analysis of medical records and administrative systems. For analysis, we used the absolute and relative frequency and multiple linear regression. Calculated rate of absenteeism-illness, frequency index, severity index and the average duration of leaves, stratified by gender and job role. The sample of 5,115 events in the population of 1,104 servers confirmed the positive relationship between age of the server, the level of schooling of the role and mental and behavioral disorders with the largest number of days of leaves. The female gender, live in the city where works, servers those did not have information on the marital status, technical-administrative job role and the public service time proved to be associated with fewer days of leave. The results presented show the relevance of absenteeism-illness in the context of federal public education and indicate the needs of interference in this sector regarding the organization of work and the health-disease process of their servers.
\end{abstract}

Keywords: Servants Health; Occupational Health; Absenteeism 


\section{INTRODUCTION}

Sickness-absenteeism is the term that defines all sick-leaves resulting from the inability of the person in the work process, ranging from a malaise until a more serious disease (SANTI \& CHEADE, 2018). The leaves from work due to illness occur due to multiple factors, including psychological, social and economic conditions; and directly linked to the activity - such as workday, hierarchy, division of tasks, among other aspects (SALA et al., 2004; NUNES et al., 2018). The environment and working conditions may be considered risk factors or aggravating health problems pre-existing in workers (LEÃO et al., 2015).

As a complex and growing phenomenon, the absenteeism-disease shows a worst case scenario for public health, causing even premature retirements (ERIKSSON et al., 2008; PIZZIO \& KLEIN, 2018). Nationally, the retirements and pensions paid early (before 60 years old), in the year 2015, corresponded to $2 \%$ of the Brazilian GDP (CONSTANZI \& ANSILIERO, 2016). According to the Ministry of Planning, Budget and Management (MPBG) in 2015, 1.3\% of the retirements of federal public servants were considered premature and $4.7 \%$ were due to disability to work (BRASIL, 2017).

With the changes in the epidemiological profile of diseases, the health of the worker has suffered a greater impact, affecting not only the productivity, but also causing the loss of working capacity of workers in the course of time (ANDRADE et al., 2008). In England, a survey indicated that the risk of early deaths increases by $66 \%$ in workers who showed sick-leaves from work for more than seven days in three years (HEAD et al., 2008).

Research indicate that the absenteeism-disease in public service varies from 2 to 14 days for each server that departs (SANTOS \& MATTOS, 2010), in addition to observe that the same server has sick-leaves more than once per year, which generates a relevant loss per day of departure (LEÃO et al., 2015). Public sector workers have more work days lost due to absenteeism-disease, as well as a longer 
period of leave, when compared to employees of private initiative, particularly in public administration affects the efficiency of tasks deemed essential to society (SALA et al., 2004).

Absenteeism-disease has become the target of concern in public organizations, both by the economic impact generated by National Treasury regarding the service shortfall, affecting society in general (GUIMARÃES et al., 2016; LEMOS et al., 2018). Regardless of the position it occupies, the worker is an important agent in the social construction, and corresponds to $10 \%$ of the total number of workers in the country, which proportionally represents half of the total number of workers in France and one-third of that Denmark employs (OCDE, 2015).

Education is an area of specific labor aspects (mainly related to stress) that can achieve the health of their workers, in virtue of the own school environment and its intersectoral relations, generating diseases that affect the quality of life not only at work, but also outside it (VIEIRA \& OLIVEIRA, 2013; SILVA \& PAES, 2016). Although often directly linked to the figure of the professor, the scope of education has its structure formed by several other workers, establishing a network of support for that education actually happen within the institutions (SILVA \& CAVEIÃO, 2016).

Such research is justified by the interest in better recognizing the reality of the effective population of servers at a federal educational institution, leading us to understand the complexity of the problem in the context of public education.

The study aims to investigate the factors associated to the number of days of absenteeism-disease of federal public servers in an educational institution and the values of rates and indices related to these leaves in the period from 2014 to 2017. Confirming the assumption that absenteeism by medical/dental leaves follow increasing over time and presents a profile with multifactorial indicators. 


\section{MATERIAL AND METHOD}

It is an observational, analytical, cross-sectional study conducted in a federal public institution of secondary, technical and higher education, about the leaves for treatment of health of servers in the period from January 2014 to December 2017. Of these servers, 916 are professors and 708 are technical-administrative, totaling 1.624 effective workers (data provided by the management department of people of the institution). There were included in the research servers that had sick-leaves for treatment of their own health started in the period from 2014 to 2017 and confirmed by medical/dental certificate. This time was determined by the beginning of the activities of the Unit SIASS in the institution, where sick-leaves began to be approved by the official system, and by the beginning of data collection in the study, which was in the middle of the year 2018, which would not be a full year for analysis. The maternity-leaves and by reason of illness of the person of the family came from the analysis, because the research has an interest in understanding the complex work-health-disease and to describe the epidemiological profile of servers in the scenario of the study.

As a technique for data collection, there was used the documentary analysis of records of servers, stored in the Unit SIASS and the consultation in databases SIAPE-Health and platform SUAP, performed in the period from August 2018 to February 2019. The Unit SIASS is responsible for approving the leaves for health reasons of servers on SIAPE-Health system (part of SIAPEnet, official site of the information from the Integrated System for Administration of Human Resources, belonging to the Ministry of Planning), perform medical/dental expertise and admission examinations, storing in their dependencies the records of all servers treated in the Unit. This institute also uses the Unified Public Administration System (SUAP), an administrative system that has as main objective the computerization and optimization of administrative processes, divided into modules, being one of them the People Management Module, which displays 
information from the functional life of the servers. To keep the confidentiality of the information the data collection tool was identified only by numbers, without reference to any server's identity.

The dependent variable was the number of days of leave. The independent variables investigated were sociodemographic characteristics (gender, age, if the server resides in the city who works and marital status), occupational (position, level of schooling over exercised, time of public service) and the leave (year of leave and referred cause as ICD-10, according OMS, 1995). First, it was performed the characterization of the population by the variables collected through absolute and relative frequency.

In the univariate analysis, to investigate differences in the average number of days of sick-leave between the sociodemographic factors, occupational and leave there was used the T-test or ANOVA according to the number of categories of each explanatory variable. Normality was tested using the Kolmogorov-Smirnov test, showing that the sample distribution is normal.

In the multivariate analysis, we used multiple linear regression, where the dependent variable was the number of sick-leave days and as independent variables the parameters that showed a statistically equal to or less than $20 \%$ in the univariate analysis. For the construction of the linear regression models, we used the stepwise backward procedure. It was established a significance equal to or less than $5 \%$ for correlation between the variables studied.

We calculated the rate of absenteeism-disease (TAD), the frequency index (IF), severity index (IG) and the average duration of leaves (DML), with recommendations of the Subcommittee of Absenteeism of the International Association of Labor Medicine (SANTOS \& MATOS, 2010; BASTOS et al., 2016). We used as a basis the number of medical leaves, the total number of employees, working days and work days lost by sick-leaves. The indicators are represented by the following formula: 


$$
\begin{gathered}
T A D=\left(\frac{\text { total days of sick leave }}{N \text { of servers } x \text { of workdays }}\right) \times 100 \\
I G=\left(\frac{N \text { of total days for sick leave }}{N \text { of servers }}\right) \\
I F=\left(\frac{\text { total of sick leaves }}{N \text { of servers }}\right) \times 10 \\
D M L=\left(\frac{N \text { of total days for sick leave }}{N \text { of sick leaves }}\right)
\end{gathered}
$$

For the calculation of the TAD, we used the number of working days for technical-administrative staff and teachers, because the amount of vacation days is different for the two categories: 228 for teachers and 239 for technicaladministrative staff, excluding Saturdays, Sundays and public holidays. In addition, the calculations were categorized by gender, thus allowing a more detailed analysis.

The program SPSS version 20 for Windows was used in the statistical analysis. The project was approved by the institution and by the Committee for Ethics in Research at the Federal University of Viçosa (Opinion N 2.714.790).

\section{RESULTS}

Five thousand one hundred-fifteen sick leaves were identified within the assessed period (2014-2017), and that there was a variation from 1 to 30 events per participant. From the total operational servers within the institution (1.624), the number who remained in the study, after applied the inclusion and exclusion criteria, there were 1.104 having an average of 4.6 leaves per server.

The sociodemographic, occupational characteristics and information about the leave of the population studied are shown in Table 1. Identifying the predominance of persons of the female gender (63.75\%), aged between 34 to 39 
years old (22.6\%) and 48 to 56 years old (21.7\%). Furthermore, the majority of the sample resides in the same city that works (63.8\%), and lived with a partner (50.7\%).

In the institution studied, the servers are called by two main categories: Teachers and Technical-Administrative in Education (TAESs), and among the TAEs there are positions of different levels of training. It should be noted that not necessarily the servers perform functions on their level of schooling: some have education degree higher than required by their positions. The analysis of occupational information identified that most participants occupy the position of technical-administrative in the institution (67.1\%) and exercises functions of higher education position (53.9\%). About 52\% of servers has less than 8 years of public service.

Five thousand one hundred-fifteen sick leaves were identified within the assessed period (2014-2017), and that there was a variation from 1 to 30 events per participant. From the total operational servers within the institution (1.624), the number who remained in the study, after applied the inclusion and exclusion criteria, there were 1.104 having an average of 4.6 leaves per server.

The sociodemographic, occupational characteristics and information about the leave of the population studied are shown in Table 1. Identifying the predominance of persons of the female gender (63.75\%), aged between 34 to 39 years old (22.6\%) and 48 to 56 years old (21.7\%). Furthermore, the majority of the sample resides in the same city that works (63.8\%), and lived with a partner (50.7\%).

In the institution studied, the servers are called by two main categories: Teachers and Technical-Administrative in Education (TAESs), and among the TAEs there are positions of different levels of training. It should be noted that not necessarily the servers perform functions on their level of schooling: some have education degree higher than required by their positions. The analysis of occupational information identified that most participants occupy the position of technical-administrative in the institution (67.1\%) and exercises functions of higher education position (53.9\%). About 52\% of servers has less than 8 years of public service. 
Table 1 - Descriptive analysis of sick leaves of federal employees of a public educational institution between 2014 and $2017(N=5.115)^{*}$

\begin{tabular}{|c|c|c|}
\hline Variables & $\mathbf{N}$ & $\%$ \\
\hline \multicolumn{3}{|l|}{ Sociodemographic Variables } \\
\hline \multicolumn{3}{|l|}{ Gender } \\
\hline Female & 3261 & $63.75 \%$ \\
\hline Male & 1854 & $36.25 \%$ \\
\hline \multicolumn{3}{|l|}{ Age (years) } \\
\hline$<=33$ & 1069 & $20.9 \%$ \\
\hline $34-39$ & 1156 & $22.6 \%$ \\
\hline $40-47$ & 846 & $16.5 \%$ \\
\hline $48-56$ & 1108 & $21.7 \%$ \\
\hline 57 or + & 936 & $18.3 \%$ \\
\hline \multicolumn{3}{|l|}{ Server resides in the city that works } \\
\hline Yes & 3262 & $63.8 \%$ \\
\hline No & 1853 & $36.2 \%$ \\
\hline \multicolumn{3}{|l|}{ Marital status } \\
\hline With a partner & 2591 & $50.7 \%$ \\
\hline Without a partner & 1357 & $26.5 \%$ \\
\hline No information & 1167 & $22.8 \%$ \\
\hline \multicolumn{3}{|l|}{ Variables about education } \\
\hline \multicolumn{3}{|l|}{ Position } \\
\hline Technical-administrative & 3431 & $67.1 \%$ \\
\hline Teacher & 1684 & $32.9 \%$ \\
\hline \multicolumn{3}{|l|}{ Level of education of the position held } \\
\hline Higher education & 2755 & $53.9 \%$ \\
\hline Technical & 1380 & $27.0 \%$ \\
\hline High school & 307 & $6.0 \%$ \\
\hline Elementary/Literate & 673 & $13.2 \%$ \\
\hline \multicolumn{3}{|l|}{ Public service time (years) } \\
\hline$<=4$ & 1323 & $26.2 \%$ \\
\hline $5-8$ & 1332 & $26.4 \%$ \\
\hline $9-24$ & 1265 & $25.0 \%$ \\
\hline 25 years or + & 1135 & $22.5 \%$ \\
\hline \multirow{2}{*}{\multicolumn{3}{|c|}{$\begin{array}{l}\text { Information about sick leave } \\
\text { Days of sick leave }\end{array}$}} \\
\hline & & \\
\hline 1 day & 1969 & $38.5 \%$ \\
\hline 2 days & 927 & $18.1 \%$ \\
\hline 3 days & 605 & $11.8 \%$ \\
\hline 4 - 8 days & 604 & $11.8 \%$ \\
\hline 9 days or + & 1010 & $19.7 \%$ \\
\hline \multicolumn{3}{|l|}{ Year of sick leave } \\
\hline 2014 & 867 & $17.0 \%$ \\
\hline 2015 & 1210 & $23.7 \%$ \\
\hline 2016 & 1597 & $31.2 \%$ \\
\hline 2017 & 1441 & $28.2 \%$ \\
\hline \multicolumn{3}{|l|}{ ICD of sick leave } \\
\hline Diseases of the respiratory system & 876 & $17.1 \%$ \\
\hline Diseases of the Musculoskeletal System and Connective Tissue & 670 & $13.1 \%$ \\
\hline
\end{tabular}




\begin{tabular}{lcc}
\hline Conclusion & & \\
\hline \multicolumn{1}{c}{ Variables } & $\mathbf{N}$ & $\mathbf{\%}$ \\
\hline ICD of sick leave & & \\
\hline Diseases of the digestive tract & 547 & $10.7 \%$ \\
Mental and Behavioral Disorders & 454 & $8.9 \%$ \\
Infectious and parasitic diseases & 450 & $8.8 \%$ \\
Diseases of the circulatory system & 344 & $6.7 \%$ \\
Other diseases & 1774 & $34.7 \%$ \\
\hline
\end{tabular}

*regarding the number of sick leave in the period studied.

Table 2 shows the quantification of the indices and rates relating to leaves by absenteeism-illness stratified per professional category and gender. It should be noted that in all the years studied, the IF, the IG and the TAD in technicaladministrative females are highest, while male teachers are those which have less value. The TAD ranged from 2.2 (2014) to 3.7 (2017) and the IG from 5.7 to 9.0 from 2014 to 2017. The value of the IF that stands out is the year of 2016, which presented the value of 104.5. On the other hand, the average duration of the leaves (DML) highlights the male gender of the two categories with high values, being that in 2014 and 2016 they had longer duration of leaves.

Table 2 - Calculations of the rate of absenteeism-disease (TAD), frequency index (IF), severity index (GA) and average duration of licenses (DML) by gender and professional category $(N=1.624)^{*}$

\begin{tabular}{|c|c|c|c|c|c|}
\hline \multirow[t]{2}{*}{ Rate of absenteeism-disease (TAD) } & \multicolumn{5}{|c|}{ Year of sick leave } \\
\hline & $\mathbf{N}$ & 2014 & 2015 & 2016 & 2017 \\
\hline Female Administrative Technician & 373 & 3.3 & 4.9 & 5.6 & 5.3 \\
\hline Male Administrative Technician & 335 & 2.4 & 2.5 & 2.9 & 4.0 \\
\hline Female teacher & 349 & 2.3 & 3.3 & 3.5 & 3.9 \\
\hline Male teacher & 567 & 1.7 & 1.1 & 2.3 & 2.1 \\
\hline Total (Average) & 1.624 & 2.2 & 2.7 & 3.5 & 3.7 \\
\hline \multirow[t]{2}{*}{ Severity Index (IG) } & \multicolumn{5}{|c|}{ Year of sick leave } \\
\hline & $\mathbf{N}$ & 2014 & 2015 & 2016 & 2017 \\
\hline Female Administrative Technician & 373 & 7.9 & 11.8 & 13.6 & 12.7 \\
\hline Male Administrative Technician & 335 & 5.8 & 6.1 & 7.0 & 9.6 \\
\hline Female teacher & 349 & 5.4 & 7.7 & 8.3 & 9.0 \\
\hline Male teacher & 567 & 3.9 & 2.7 & 5.4 & 4.8 \\
\hline Total (Average) & 1.624 & 5.7 & 7.0 & 8.6 & 9.0 \\
\hline
\end{tabular}




\begin{tabular}{lccccc}
\hline Conclusion & \multicolumn{5}{c}{ Year of sick leave } \\
\hline Frequency Index (IF) & $\mathbf{N}$ & $\mathbf{2 0 1 4}$ & $\mathbf{2 0 1 5}$ & $\mathbf{2 0 1 6}$ & $\mathbf{2 0 1 7}$ \\
\hline Female Administrative Technician & 373 & 103. & 149.0 & 201.0 & 179.3 \\
Male Administrative Technician & $\mathbf{4}$ & $\mathbf{4}$ & & & \\
Female teacher & 335 & 57.3 & 84.4 & 92.5 & 85.3 \\
Male teacher & 349 & 41.5 & 56.7 & 84.2 & 70.4 \\
\hline Total (Average) & 567 & 25.5 & 29.6 & 40.5 & 42.3 \\
\hline Average duration of sick leaves (DML) & $\mathbf{1 . 6 2 4}$ & $\mathbf{5 6 . 9}$ & $\mathbf{7 9 . 9}$ & $\mathbf{1 0 4 . 5}$ & $\mathbf{9 4 . 3}$ \\
\hline & $\mathbf{N}$ & $\mathbf{2 0 1 4}$ & $\mathbf{2 0 1 5}$ & $\mathbf{2 0 1 6}$ & $\mathbf{2 0 1 7}$ \\
\hline Female Administrative Technician & 373 & 7.6 & 7.9 & 6.7 & 7.1 \\
Male Administrative Technician & 335 & 10.0 & 7.2 & 7.6 & 11.2 \\
Female teacher & $\mathbf{3 4 9}$ & 12.9 & 13.5 & 9.5 & 12.8 \\
Male teacher & 567 & 15.3 & 9.0 & 13.2 & 11.4 \\
\hline Total (Average) & $\mathbf{1 . 6 2 4}$ & $\mathbf{1 1 . 4}$ & $\mathbf{9 . 4}$ & $\mathbf{9 . 2}$ & $\mathbf{1 0 . 6}$ \\
\hline
\end{tabular}

*regarding the total number of servers.

To perform the analysis of factors associated to the number of workdays lost (Table 3), it is observed statistically significant associations between all the variables studied ( $p$-value $<0.05$ ). The average number of days of leaves is greater on the servers of the male gender (10.30 [22.79]), residing in different cities of which work (11.69 [25.48]) and lowest in those who do not have information on the marital situation $(8.30$ [18.95]). In relation to age, it should be noted that the average number of days of leave increases with the growing age. It should be noted that in spite of the younger adults to depart from a larger number of times (34-39 years old), there is an increasing gradient as the average number of days of sick leave: younger people depart on average 6.75 days, while older servers away an average of 10.26 days.

On the occupational variables, it should be noted that the post with higher median is the docent (11.97 [24.61]), and the levels of education office that stand out are those of higher level (9.94 [22.06]) and the lowest level (11.40 [22.74]), in addition to the period of 9 to 24 years of public service (11.35 [23.39]).

In relation to the data from the leaves of the servers in the period studied, the first year (2014) was the one that presented longer events (10.38 [23.32]) and it is evident that the mental and behavioral disorders (27.41 [34.57]) depart by more time servers, compared to all other existing CIDs (Table 3). 
Table 3 - Univariate analysis of factors associated with the number of days away from federal employees of a public educational institution between 2014 and 2017 ( $\mathrm{N}=$ $5.115)^{*}$

\begin{tabular}{|c|c|c|}
\hline \multirow{2}{*}{ Variables } & \multicolumn{2}{|c|}{ Number of days away } \\
\hline & Average (SD) & P-value \\
\hline$\overline{\text { Gender ** }}$ & & 0.003 \\
\hline Female & $8.53(19.08)$ & \\
\hline Male & $10.30(22.79)$ & \\
\hline Age (years) $* * *$ & & $<0.001$ \\
\hline$<=33$ & $6.75(15.88)$ & \\
\hline $34-39$ & $8.94(19.60)$ & \\
\hline $40-47$ & $10.01(21.87)$ & \\
\hline $48-56$ & $10.20(23.32)$ & \\
\hline 57 or + & $10.26(21.31)$ & \\
\hline Server resides in the city that works ${ }^{* *}$ & & 0.034 \\
\hline Yes & $7.74(16.90)$ & \\
\hline No & $11.69(25.48)$ & \\
\hline Marital status*** & & 0.017 \\
\hline With a partner & $9.32(20.05)$ & \\
\hline Without a partner & $9.64(22.60)$ & \\
\hline No information & $8.30(18.95)$ & \\
\hline Position** & & $<0.001$ \\
\hline Administrative technician & $7.80(18.02)$ & \\
\hline Teacher & $11.97(24.61)$ & \\
\hline Level of education of the position held $* * *$ & & $<0.001$ \\
\hline Higher education & $9.94(22.06)$ & \\
\hline Technician & $7.36(16.98)$ & \\
\hline High school & $5.58(13.26)$ & \\
\hline Elementary/Literate & $11.40(22.74)$ & \\
\hline Public service time (years) ${ }^{* * *}$ & & $<0.001$ \\
\hline$<=4$ & $8.20(19.74)$ & \\
\hline $5-8$ & $7.67(16.82)$ & \\
\hline $9-24$ & 11.35 (23.39) & \\
\hline 25 or + & $8.43(18.81)$ & \\
\hline Year of sick leave*** & & 0.022 \\
\hline 2014 & $10.38(23.32)$ & \\
\hline 2015 & $8.82(21.73)$ & \\
\hline 2016 & $8.37(18.43)$ & \\
\hline 2017 & $9.63(19.83)$ & \\
\hline ICD of sick leave ${ }^{* * *}$ & & $<0.001$ \\
\hline Diseases of the respiratory system & $3.09(6.42)$ & \\
\hline Diseases of the musculoskeletal system and connective tissue & $8.62(17.14)$ & \\
\hline Diseases of the digestive tract & $4.25(10.47)$ & \\
\hline Mental and Behavioral Disorders & $27.41(34.57)$ & \\
\hline Infectious and parasitic diseases & $3.23(5.29)$ & \\
\hline Diseases of the circulatory system & $8.47(18.19)$ & \\
\hline Other diseases & $10.88(23.45)$ & \\
\hline
\end{tabular}

* regarding the number of sick leaves in the period studied ${ }^{* \star T}$ T-test ${ }^{* \star \star}$ ANOVA 
In the multivariate analysis (Table 4 ) there were associated with more days of leave from work the age ranges from 48 to 56 years old ( $C R=1.78 ; 95 \% \mathrm{Cl}$ : 0.29 3.27) and $57(C R=2.49 ; 95 \% \mathrm{Cl}: 0.66-4.34)$, the positions of less schooling ( $C R=2.62$; $95 \% \mathrm{Cl}: 0.96-4.28)$ and between the groups of diseases that generated leaves, in accordance with the chapters of the ICD-10, which showed more days were the mental and behavioral disorders ( $C R=22.30 ; 95 \% \mathrm{Cl}: 20.34-24.25)$, the category "Other diseases" ( $C R=7.26 ; 95 \% \mathrm{Cl}: 6.03-8.48)$, diseases of the musculoskeletal system and connective tissue $(\mathrm{CR}=4.88 ; 95 \% \mathrm{Cl}$ : 3.22-6.55), and the circulatory diseases ( $C R=4.27 ; 95 \% \mathrm{Cl}: 2.07-6.47)$. Less days of removal were presented by servers in the female gender [CR=(-1.13); $95 \% \mathrm{Cl}:(-2.25)-(-0.02)]$, server that resides in the same city that works [CR=(-2.83); 95\% Cl:(-3.98)-(-1.69)], when there is no information on the marital [CR $=(-2.52) ; 95 \% \mathrm{Cl}:(-3.87)-(-1.17)]$ and when occupying position of administrative technician [CR=(-4.46); 95\% Cl:(-5.62)-(-3.29)]. In relation to public service, three categories were associated with having fewer days of absence from work: 4 years or less [CR $=(-2.56) ; 95 \% \mathrm{Cl}:(-4.15)-(-0.96)], 5$ to 8 years [CR=(-3.36); 95\% Cl:(-4.92)-(-1.81)] and 25 years or more [CR=(-2.77); 95\% Cl:(-4.45)$(-1.09)]$.

Table 4 - Multivariate Analysis of Linear Regression of factors associated with the number of days away from federal employees of a public educational institution between 2014 and $2017(\mathrm{~N}=5.115)^{*}$

\begin{tabular}{|c|c|c|c|c|}
\hline \multirow[t]{2}{*}{ Variables } & \multirow[t]{2}{*}{ Regression Coefficient } & \multicolumn{2}{|c|}{$\begin{array}{c}\text { 95\% Confidence } \\
\text { Interval }\end{array}$} & \multirow[t]{2}{*}{ P-Value } \\
\hline & & Low & Upper & \\
\hline \multicolumn{5}{|l|}{ Gender } \\
\hline Female & -1.13 & -2.25 & -0.02 & 0.046 \\
\hline \multicolumn{5}{|l|}{ Age (years) } \\
\hline $48-56$ & 1.78 & 0.29 & 3.27 & 0.019 \\
\hline 57 or + & 2.49 & 0.66 & 4.34 & 0.008 \\
\hline \multicolumn{5}{|c|}{$\begin{array}{l}\text { Server resides in the city that } \\
\text { works }\end{array}$} \\
\hline Yes & -2.83 & -3.98 & -1.69 & $<0.001$ \\
\hline \multicolumn{5}{|l|}{ Marital status } \\
\hline No information & -2.52 & -3.87 & -1.17 & $<0.001$ \\
\hline \multicolumn{5}{|l|}{ Position } \\
\hline Administrative technician & -4.46 & -5.62 & -3.29 & $<0.001$ \\
\hline \multicolumn{5}{|l|}{$\begin{array}{l}\text { Level of education of the } \\
\text { position held }\end{array}$} \\
\hline Elementary/Literate & 2.62 & 0.96 & 4.28 & 0.002 \\
\hline
\end{tabular}




\begin{tabular}{|c|c|c|c|c|}
\hline \multicolumn{5}{|l|}{ Conclusion } \\
\hline \multirow[t]{2}{*}{ Variables } & \multirow[t]{2}{*}{ Regression Coefficiente } & \multicolumn{2}{|c|}{$\begin{array}{c}\text { 95\% Confidence } \\
\text { Interval }\end{array}$} & \multirow[t]{2}{*}{ P-Value } \\
\hline & & Low & Upper & \\
\hline \multicolumn{5}{|l|}{ Public service time (years) } \\
\hline$<=4$ & -2.56 & -4.15 & -0.96 & 0.002 \\
\hline $5-8$ & -3.36 & -4.92 & -1.81 & $<0.001$ \\
\hline 25 or + & -2.77 & -4.45 & -1.09 & 0.001 \\
\hline \multicolumn{5}{|l|}{ ICD of sick leaves } \\
\hline $\begin{array}{l}\text { Diseases of the musculoskeletal } \\
\text { system and connective tissue }\end{array}$ & 4.88 & 3.22 & 6.55 & $<0.001$ \\
\hline Mental and Behavioral Disorders & 22.30 & 20.34 & 24.25 & $<0.001$ \\
\hline $\begin{array}{l}\text { Diseases of the circulatory } \\
\text { system }\end{array}$ & 4.27 & 2.07 & 6.47 & $<0.001$ \\
\hline Other diseases & 7.26 & 6.03 & 8.48 & $<0.001$ \\
\hline
\end{tabular}

*regarding the number of sick leaves in the period studied.

\section{DISCUSSION}

The results of this study present data on the indicators of absenteeismillness, as well as the sociodemographic and occupational profile of the servers in the years of the study. The values of rates and indices related to absenteeismillness presented in different years, as is the case of this research, may indicate the importance of taking measures in relation to human resources, revealing to managers the conditions of the organization's environment, and may assist in the planning and management of actions on worker's health and/or assess the effectiveness of the same (LEÃO et al., 2015).

We emphasize that the values found by TAD and IG (which represent respectively the percentage of absenteeism within the institution and the severity of the morbidities that reach the servers considering the time of the sick leave) had an increasing trend between the years studied. For the International Labor Organization, the rate of absenteeism-illness acceptable is 2.5; what makes us consider the rates from 2015 to 2017 high (CAMPION, MELO \& MONTEIRO, 2013). However, considering the literature, these indices are at the same level of studies performed in other countries, such as in the United Kingdom, which indicate a 
variation of 3.5 to 6.5, and in Brazil, on servers from Rio Grande do Sul, where the rates found were 3.9 and 3.7 (SANTOS \& MATTOS, 2010; BASTOS et al., 2016). The IG expresses the average number of working days lost per server per year, the total population of the study, indicating the magnitude of absenteeism-illness. This study was calculated by separating gender and position, regardless of who had or not leave by disease. The values found were close to those found in the study conducted with public servers of Goiania (LEÃO et al., 2015).

Already the IF (which represents the prevalence of leaves within the institution) did not show the same growing tendency that the TAD and the IG, because it has decreased last year of the study period, but remained at high levels, from 2015 to 2017, if considered the value accepted by the OIT, which is above 60 (SUMAMEN et al., 2015). Comparing the values of the IF found in this study with those of other studies performed in public servers, we noticed that the IF identified in the present study has relevance (SANTOS \& MATTOS, 2010; LEMOS et al., 2018). In recent years, since the beginning of the expansion of Federal Institutions of Higher Education (IFES), many changes have occurred with respect to the management of people and the organization of work within these institutes, which directly affects the servers, and may be related to increased stress in the work environment (MARIN \& SCHERER, 2012; LEAL, SOUZA \& MOREIRA, 2018) which can justify the high IF.

On the associations with more days of leave, we can highlight the positive relationship between the increase in age and the increase of days of sick leave. This finding validates data from other studies that have identified an increase of leaves for the treatment of health with increasing age of workers, reaching the conclusion that this increase may be linked to other reasons besides health problems, as related to motivational factors (SANTI \& CHEADE, 2018; LEMOS et al., 2018; PIZZIO \& KLEIN, 2018; RAMOS \& MACÊDO, 2018). Other articles find more leaves between the age ranges of 30 to 40 years old (SANTI \& CHEADE, 2018; LEMOS et al., 2018). It is supposed, through evidences, that, within 20 years, more than half of the 
composition of the national population will be of individuals above 45 years old, which brings up the discussion about the worker's ability to, taking into account that the functional aging lead to chronological aging (SANTI \& CHEADE, 2018; DIAS et al., 2018).

The educational level of the position also had an inverse association with the number of workdays lost. This confirms the findings of other studies, national and international, with state servants, who concluded that the absenteeism-illness is higher in individuals with positions with lower remuneration and with the requirement of less schooling, especially in the education sector (SANTI \& CHEADE, 2018; LEÃO et al., 2015; LEMOS et al., 2018; BASTOS et al., 2018).

Despite the mental and behavioral disorders present themselves as the fourth leading cause of absenteeism-disease, the same show association with a higher number of days of leaves, representing an increase of 22.30 days on sick leaves when compared to other diseases. Other studies those evaluated the diseases that away the public servers indicated the mental and behavioral disorders as one of the main causes of sick leaves, associating this group the trend of increase of average of workdays lost over time (BARBOZA \& SANTOS, 2018; MARANGONI et al., 2016; SANTA-MARINHA et al., 2018). In studies with teachers, it was found that the mental and behavioral disorders are in the group of the CID that most away in this category, which may relate to the school environment, excessive pace and the structural organization of work (CECCON et al., 2014). The perception of work as source of stress and the coexistence with people those negatively influence the work environment are factors that have contributed to the development of Burnout Syndrome in public servers of Tocantins (BENZONI, 2018). Alarming data on suicide appear in some of the studies: technical-administrative servers of a federal institution of higher education that had a mood disorder, anxiety disorders and depression reported having had suicidal ideas or have attempted suicide, motivated by the organization of work (BASTOS et al., 2018). 
Another group that stands out are the diseases of the musculoskeletal system and the connective tissue, representing 4.88 more days of leave by these morbidities. Research conducted in an educational institution with the same characteristics as the present study shows that the two main causes of sick leave and lost days of work are consecutively mental disorders and musculoskeletal diseases (MARANGONI et al., 2016). Countries such as Norway and Spain also have the mental disorders and the musculoskeletal diseases as the main causes of long leaves from work (BARBOZA \& SANTOS, 2018).

The categories female gender, server living in the city who works and technical-administrative position show less days of leaves, as well as three categories of the variable "time of public service": 4 years or less, 5 to 8 years and 25 years or more. About the relationship of gender, it was found in the present study that, although less days, the quantities of events those make away females are higher than males. This converges with several other studies that have investigated the absenteeism-illness and relate them to gender. 7,10 The fact that women present more events, but with lower average of days of leaves than men, based on the hypothesis that male servers only leave in more severe cases and which require more days of treatment (LEÃO et al., 2015; LEMOS et al., 2018).

Reside in the same city that works has influence on the task of lower averages of workdays lost due to illness. This result goes against other studies those in dicate the demotivation for assiduity when the worker has to travel long distances to get to work, concluding that the size of the residence-work transfer may have a great influence on the absence of the worker (RODRIGUES et al., 2013; FURLAN \& STANCATO, 2013).

To be a server in technical-administrative positions of the institution indicated relationship with lower average of sick leave days, which converges with the results of DML. However, in relation to the frequency of events, we note a higher number of technical-administrative servers away by reason of illness. It is concluded that the technical-administrative staff have a higher number of events 
of sick leaves, but the teachers remain more working days away. This difference in frequency and amount of days may be related to distinct characteristics that categories have, taking into account that the working regime and careers are described in different laws (PINHO, 2014; BRASIL, 2005).

As a limitation of the study records the low quality of data available in the system SIAPE-Health/SIASS, which presents the occupational data and the sick leaves of the servers. To minimize this low quality, we used other data sources, collecting the information from medical records and SUAP platform. Some variables (race/color and existing diseases at baseline server) had to be excluded from the analyses because they did not present sufficient amount of information, even with the use of more than one database for the collection.

\section{CONCLUSIONS}

In conclusion, the average number of days of leave in public servers of a teaching institution was associated with age, gender, schooling, marital status, place of residence of the server, a position he holds in the educational institution, public service time and the diseases grouped into chapters of ICD 10. The mental and behavioral disorders stood as the diseases that more time make away the server from work. The values of the TAD and IG had a growing trend among the years studied.

The present study showed indicative of the need for intervention and the urgency of effective actions to improve working conditions and serves as reference for future research. The factors those relate to the absenteeism-disease in public servers of an institution in particular allows the creation of strategies and action plans turned to the reality of each component, making possible the elaboration of policies for promotion, prevention and more effective health care, which favors both the public power as the servers themselves, humanizing the relation of labor- 
worker, favoring a better performance of this server in his work, and consequently increasing the levels of well-being and satisfaction of the employees.

\section{REFERENCES}

ANDRADE, Tania Bof. et al. Prevalência de absenteísmo entre trabalhadores do serviço público. Sci. med., Porto Alegre, v. 18, n. 4, p. 166-171, Oct./Dec. 2008.

BARBOZA, Elisana Ligia Garcia; SANTOS, Marta Azevedo dos Santos. Afastamento para Tratamento da Própria Saúde e suas Implicações na Prática Profissional. In: CONGRESSO IBERO-AMERICANO EM INVESTIGAÇÃO QUALITATIVA, 7.,2018, Fortaleza. Anais [...]. Fortaleza: Universidade de Fortaleza, 2018, p. 81-90.

BASTOS, Maria Luiza Almeida et al. Afastamentos do trabalho por transtornos mentais: um estudo de caso com servidores públicos em uma instituição de ensino no Ceará, Brasil. Rev Bras Med Trab., São Paulo, v. 16, n. 1, p. 53-59, Jan. 2018.

BASTOS, Vitor Guerzet Ayres; SARAIVA, Patricia Grativol Costa; SARAIVA, Fábio Petersen. Absenteísmo-doença no serviço público municipal da Prefeitura Municipal de Vitória. Rev Bras Med Trab., São Paulo, v. 14, n. 3, p. 192-201. 2016.

BRASIL. Lei no 11.091, de 12 de janeiro de 2005. Dispõe sobre a estruturação do Plano de Carreira dos Cargos Técnico-Administrativos em Educação, no âmbito das Instituições Federais de Ensino vinculadas ao Ministério da Educação, e dá outras providências. Diário Oficial da União, Brasília (DF); 13 jan 2005.

BRASIL. Lei no 12.772, de 28 de dezembro de 2012. Dispõe sobre a estruturação do Plano de Carreiras e Cargos de Magistério Federal [...] e da outras providências. Diário Oficial da União, Brasília (DF); 31 dez 2012.

BRASIL. Ministério de Planejamento, Orçamento e Gestão. Boletim Estatístico de Pessoal e Informações Organizacionais. Brasília 2017; n. 249.

CANTOR CUTIVA, Lady Catherine; BURDORF, Alex. Medical costs and productivity costs related to voice symptoms in Colombian teachers. J Voice, New York, v. 29, n. 6, p. 776 e15-22, Nov. 2015.

CECCON, Roger Flores et al. Suicídio e trabalho em metrópoles brasileiras: um estudo ecológico. Ciênc. saúde coletiva, Rio de Janeiro, v. 19, n. 7, p. 2225-2234, July 2014.

CONSTANZI RN, ANSILIERO G. As Idades médias de aposentadoria urbana por Unidade da Federação e região. IPEA (NT) 2016; n. 29. 
DIAS, Adriano et al. Factors Affecting Sick Leave Duration for Non-Work-Related Temporary Disabilities in Brazilian University Public Servants. Int. J. Environ. Res. Public Health, Basel, v. 15, n. 10, p. 2127, Oct. 2018.

ERIKSSON, Hans G. et al. Sickness absence and self-reported health a population-based study of 43,600 individuals in central Sweden. BMC Public Health, London v. 8, p. 426, Dec. 2008.

FURLAN, Jussara Aparecida da Silva; STANCATO, Kátia. Fatores geradores do absenteísmo dos profissionais de enfermagem de um hospital público e um privado. RAS, São Paulo, v. 15, n. 60, p. 111-20, July/Sept. 2013.

GUIMARÃES, Grazielly Fagundes Magnago et al. Absenteísmo no setor público: um estudo de caso no Espírito Santo. Revista Científica Intelletto, Venda Nova do Imigrante v. 1, n. 1, p. 1523, 2016.

$H E A D$, Jenny et al. Diagnosis-specific sickness absence as a predictor of mortality: the Whitehall II prospective cohort study. BMJ, [s. I.], n. 337, p. 1-7, 2008.

LE CAMPION, Anna Carolina Omena Vasconcellos. Perfil do absenteísmo-doença nos servidores públicos federais na Unidade SIASS/INSS/Alagoas. Cognitio. v. 1, n. 1, p. 1-9, 2013.

LEAL, Fernanda Geremias; SOUZA, Stefani de, MOREIRA, Kátia Denise. Atuação do secretário executivo na gestão universitária pública: o estado do conhecimento sobre a questão. Revista de Gestão e Secretariado, São Paulo, v. 9, n. 1, p. 65-89, 2018.

LEÃO, Ana Lúcia de Melo et al. Absenteísmo-doença no serviço público municipal de Goiânia. Rev Bras Epidemiol., São Paulo, v. 18, n. 1, p. 262-77, 2015.

LEMOS, Diogo Sousa et al. Absenteísmo-doença entre servidores públicos do setor saúde do Distrito Federal. Rev Bras Med Trab., São Paulo, v. 16, n. 3, p. 336-45, 2018.

MARANGONI, Vívian Silva Lima et al. Afastamento laboral por transtornos mentais entre servidores da prefeitura de Manaus: uma análise preliminar. Semina: Ciências Biológicas e da Saúde, Londrina, v. 37, n. 2, p. 13-24, 2016.

MARIN GS, SCHERER FL. A administração pública no controle de frequência dos agentes públicos. 2012. Monografia (Especialização em Gestão Pública Municipal) - Universidade Federal de Santa Maria, Centro de Ciências Sociais e Humanas, Rio Grande do Sul, 2012.

NUNES, Ana P. et al. The Effect of Employee Assistance Services on Reductions in Employee Absenteeism. J Bus Psychol, New York, v. 33, p. 699-709, 2018.

OECD; Organisation for Economic Co-operation and Development. Government at a Glance 2015. OECD Publishing, Paris. 2015. 214 p. 
OMS. Organização Mundial de Saúde. Classificação internacional de doenças e problemas relacionados à saúde: 10ª revisão. São Paulo: OMS, 1995.

PAULA, Jessyca Brennand et al. Incidência de transtornos mentais em servidores públicos: implicações na qualidade de vida do trabalhador. R. bras. Qual. Vida, Ponta Grossa, v. 10, n. 1, p. e7121, Jan./Mar. 2018.

PIZZIO, Alex; KLEIN, Karla Barbosa. Perfil epidemiológico dos servidores públicos federais no Tocantins afastados por motivo de saúde. G\&DR., [s.I.], v. 14, p. 588-604, Apr. 2018.

RAMOS, Lila de Fátima De Carvalho; MACÊDO, Kátia Barbosa. Reflexões sobre o adoecimento dos servidores técnico-administrativos em educação. Argum, Vitória, v. 10, n. 3, p. 107-122, Aug./Dec. 2018.

RODRIGUES, Celeste de Souza et al. Absenteísmo-doença segundo autorrelato de servidores públicos municipais em Belo Horizonte. R. bras. Est. Pop., Rio de Janeiro, v. 30, Sup., p. S135S154, 2013.

SALA, Arnaldo et al. Licenças médicas entre trabalhadores da Secretaria de Estado da Saúde de São Paulo no ano de 2004. Cad. Saúde Pública, Rio de Janeiro, v. 25, n. 10, p. 2168-2178, Oct. 2009.

SANTA-MARINHA, Marden Samir. Avaliação das licenças para tratamento de saúde implantação do Subsistema Integrado de Atenção à Saúde do Servidor na FIOCRUZ: quadriênio 2012-2015. Rev Bras Med Trab., São Paulo, v. 16, n. 1, p. 67-70, 2018.

SANTI, Daniela Bulcão; BARBIERI, Ana Rita; CHEADE, Maria de Fátima Meinberg. Absenteísmodoença no serviço público brasileiro: uma revisão integrativa da literatura. Rev Bras Med Trab., São Paulo, v. 16, n. 1, p. 71-81, 2018.

SANTOS, Jandira Pereira dos; MATTOS, Airton Pozo de. Absentismo-doença na prefeitura municipal de Porto Alegre, Rio Grande do Sul, Brasil. Rev. bras. Saúde ocup., São Paulo, v. 35, n. 121, p. 148-56, Jan./June 2010.

SILVA, Mariana Moreira; CAVEIÃO, Cristiano Caveião. Análise dos afastamentos de saúde dos trabalhadores de ensino de Divinópolis - MG. Revista Saúde e Desenvolvimento, São José do Rio Preto v. 10, n. 5, p. 138-56, July/Dec. 2016.

SILVA, Sandra Alves da; PAES, Maione Silva Louzada. Caracterização do absenteísmo dos docentes da rede municipal de Coronel Fabriciano - MG. Revista Enfermagem Integrada, Ipatinga, v. 9, n. 1, July/Aug.. 2016.

SUMAMEN, Hilla. et al. Sickness absence among young employees: trends from 2002 to 2013. J Occup Health, Tokyo, v. 57, n. 5, p. 474-81, 2015. 
VIEIRA, Luiz Fernando Sempionato. Cultura e clima organizacional: as causas do absenteísmo visto como efeito e não como causa do comportamento organizacional. RBADM, Aquidabã v. 5, n. 1, p. 82-95, 2014.

\section{Authorship contributions}

\section{1 - Bárbara de Oliveira Figueiredo}

Instituto Federal do Rio de Janeiro, Mestrado em Ciências da Saúde https://orcid.org/0000-0003-4632-6500 - barbara.figueiredo@iff.edu.br Contribuição: Conceptualization, Data curation, Investigation, Methodology, Formal Analysis, Writing - original draft

\section{2 - Luiz Sérgio Silva}

Universidade Federal de Minas Gerais, Doutorado em Saúde Pública https://orcid.org/0000-0002-3517-6941 - luizsergios@yahoo.com.br Contribuição: Conceptualization, Methodology, Writing - review \& editing

\section{3 - Renata Maria Colodette}

Universidade Federal de Viçosa, Mestrado em Ciências da Saúde https://orcid.org/0000-0002-2976-881X - renatacolodette@yahoo.com.br Contribuição: Writing - review \& editing

\section{4 - Luiza Possa Pereira}

Universidade Federal de Viçosa, Graduação em Enfermagem https://orcid.org/0000-0003-2070-2854 - possapluiza@gmail.com Contribuição: Data curation, Writing - original draft

\section{5 - Larissa Bruna Bhering Silva}

Universidade Federal de Viçosa, Graduação em Enfermagem https://orcid.org/0000-0002-6403-1362 - lala2149@gmail.com Contribuição: Data curation, Writing - original draft

\section{6 - Deíse Moura de Oliveira}

Universidade Federal de Viçosa, Doutorado em Ciências https://orcid.org/0000-0003-3804-7413 - dmouradeoliveira@gmail.com Contribuição: Writing - review \& editing

\section{7 - Tiago Ricardo Moreira}

Universidade Federal de Viçosa, Doutorado Saúde Pública https://orcid.org/0000-0002-6606-4942 - tiago.ricardo@ufv.br Contribuição: Project administration, Supervision, Formal Analysis, Writing - review \& editing 